\section{What would you ask lan Brack?}

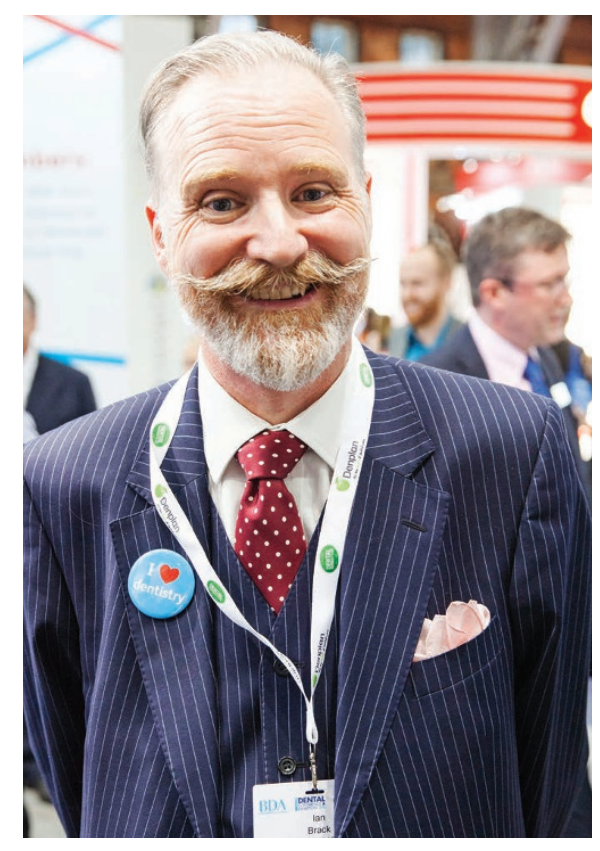

BDJ News Editor Kate Quinlan will be interviewing Ian Brack in August this year. We would like to invite readers of the $B D J$ to propose a question that they would like $\mathrm{Mr}$ Brack to answer.

Ian Brack was confirmed as the new permanent Chief Executive and Registrar of the General Dental Council (GDC) in May this year, following his time as an interim since 11 January 2016. He was previously Interim Chief Executive at the Office for Legal Complaints where he oversaw significant internal change while enhancing relationships with key external stakeholders, and also led the Olympic Lottery Distributor where he oversaw substantial grant expenditure, including the multi-million pound grant for the Paralympics.

Prior to Ian Brack, Evlynne Gilvarry held the post of Chief Executive and Registrar of the GDC for five years.

If you would like to propose a question to be asked of Ian at the interview, please email it to Kate Quinlan, k.quinlan@nature.com, by Friday 29 July 2016.

A selection of questions will be chosen for the interview by the $B D J$ editorial team.

\section{How to get published - autumn workshop}

The British Dental Editors' Forum (BDEF) is to hold a workshop for new authors at the British Dental Association (BDA) on 25 October 2016.

The aims of the workshop are to help delegates understand how papers and articles submitted to scientific journals are reviewed and assessed by editors and their teams, and improve the chances that papers and articles that they submit to peer reviewed journals are accepted. Delegates will gain a clear understanding of the need to follow a journal's guidelines for authors to the letter, the peer review process, plagiarism, publication ethics, and how to write for scientific journals.

The programme will be jointly chaired by Stephen Hancocks and Ken Eaton and will run from 11 am to $5 \mathrm{pm}$. The delegate fee is $£ 40$ and cheques payable to the British Dental Association should be sent to Stephen Hancocks, BDA, 64 Wimpole Street, London, W1G 8YS. For further details email stephen. hancocks@bda.org. 